\title{
PERSENTASE KEBERHASILAN OPERASI CIMINO DAN AV-SHUNT CUBITI PADA PASIEN HEMODIALISA DI RSUP PROF KANDOU PERIODE JANUARI 2013 - DESEMBER 2013
}

\author{
Cliff W. Sulangi, Hilman Limpeleh, Alwin Monoarfa \\ Bagian Bedah Fakultas Kedokteran Universitas Sam Ratulangi Manado \\ Email: cliffsulangi@ymail.com
}

\begin{abstract}
The procedure of access hemodialysis is a vascular surgical procedure. Vascular access is indicated in patients with end stage renal disease (ESRD) or patients with end stage chronic renal failure and had to take process on hemodialysis. Cimino and AV-Shunt cubiti is two techniques of vascular access operation. This research aims to know the percentage of successful cimino and av-shunt cubiti operation in RSUP Prof Kandou at 2013. This research was conducted using a retrospective descriptive methods. This research subjects were 37 patients. 22 patients with cimino and 15 patient with av-shunt cubiti. The result of this research obtained success percentage use $63,6 \%$ of cimino and the percentage of successful use of avshunt cubiti is $66,7 \%$.

Key words: Vascular access, Ciminom av-shunt cubiti, successful percentage

Abstrak: Prosedur dari akses hemodialisa merupakan prosedur operasi vaskular. Akses vaskular diindikasikan pada pasien dengan end stage renal disease (ERSD) atau pasien dengan gagal ginjal kronik stadium akhir dan harus menjalani proses hemodialisa. Operasi Cimino dan AVShunt Cubiti merupakan dua teknik operasi akses vaskular. Penelitian ini bertujuan untuk mengetahui prosentase keberhasilan operasi Cimino dan AV-shunt cubiti pada pasien hemodialisa di RSUP Prof Kandou tahun 2013. Penelitian ini dilakukan menggunakan metode deskriptif retrospektif. Subyek penelitian Berjumlah 37 pasien. 22 pasien operasi Cimino dan 15 pasien dengan AV-Shunt cubiti. Hasil penelitian ini didapatkan Prosentase keberhasilan penggunaan Cimino sebesar 63,6 \% dan prosentase keberhasilan penggunaan AV-Shunt cubiti sebesar 66,7\%.
\end{abstract}

Kata Kunci: Akses vaskular, Operasi Cimino, AV-shunt cubiti, prosentase keberhasilan

Lebih dari $10 \%$ atau 20 juta orang berusia 20 tahun atau lebih di US menderita penyakit ginjal kronik (Chronic Kidney Disease/ CKD). Tahun 2007, sekitar 110.000 pasien di US dengan CKD berlanjut menjadi gagal ginjal (End Stage Renal Disease/ ESRD). Pengobatan pilihan untuk ERSD adalah hemodialisa atau transplantasi organ ginjal. ${ }^{1}$

Lebih dari 300.000 individu di US mengandalkan akses vaskular untuk menerima terapi hemodialisis. Akses vaskular terus menjadi penyebab utama untuk rawat inap dan morbiditas pada pasien dengan gagal ginjal. ${ }^{2}$

Akses vaskular yang ideal memberikan dosis optimal, terapi yang adekuat, digunakan jangka panjang dan memiliki angka morbiditas serta angka mortalitas yang rendah. Terdapat hubungan yang signifikan antara tipe penggunaan akses dan tingkat morbiditas pada pasien. ${ }^{3}$

Arteriovenous Fistula (AVF) merupakan salah satu teknik akses vaskular yang paling sering digunakan dan memberikan hasil yang lebih baik dibandingkan dengan teknik yang lainnya. Dibutuhkan penempatan yang tepat bagi akses AVF.

Fakta yang ada adalah masih tingginya angka kegagalan pemasangan AVF. Komplikasi dari akses vaskular merupakan penyebab tersering terjadinya kegagalan dan rawat inap pada 
pasien dialisis. Terbatasnya data untuk memahami komplikasi AVF terutama stenosis dan thrombosis juga menghambat keberhasilan teknik AVF.. ${ }^{3-5}$

Berdasarkan penelitian, penggunaan AVF sebelum 14 hari dibuat, meningkatkan resiko terjadinya kegagalan. Penelitian ini juga menunjukkan bahwa menggunakan AVF setiap saat setelah 14 hari dibuat, tidak menunjukkan peningkatan resiko yang signifikan. ${ }^{6}$

Operasi cimino dan AV-shunt cubiti merupakan teknik operasi AV fistula. Operasi cimino merupakan pilihan pertama pada teknik AVF sedangkan AV shunt cubiti merupakan pilihan kedua. Namun angka kegagalan dari kedua teknik ini masih tinggi. ${ }^{2,4}$

Berdasarkan masalah yang diuraikan di atas, maka peneliti ingin mengetahui prosentase keberhasilan operasi Cimino dan AV-shunt cubiti pada pasien hemodialisa di RSUP. Prof.Dr. R. D. Kandou tahun 2013.

\section{METODE PENELITIAN}

Penelitian ini merupakan penelitian deskriptif retrospektif. Pelaksanaan penelitian dilakukan pada bulan Desember 2013 sampai Januari 2014 yan bertempat di bagian bedah RSUP Prof Kandou dan Bagian Hemodialisa. Subyek penelitian ini adalah seluruh pasien gagal ginjal yang menggunakan cimino dan AV-Shunt cubiti sebagai akses vaskular untuk hemodialisa yang memiliki data dan variable lengkap.

Data yang diperoleh kemudian disajikan dalam bentuk tabel distribusi untuk mendapatkan prosentase keberhasilan cimino dan AV-Shunt cubiti.

\section{HASIL PENELITIAN}

Berdasarkan penelitian yang dilakukan secara retrospektif di bagian Bedah dan Instalasi Tindakan Khusus Hemodialisa di RSUP Prof Kandou Manado Periode Januari 2012 - Desember 2012, terkumpul 22 pasien yang menggunakan operasi Cimino sebagai akses vaskular dan 15 pasien yang menggunakan AV-Shunt Cubiti sebagai akses vaskular untuk hemodialisa

Tabel 1. Distribusi keberhasilan operasi cimino berdasarkan jenis kelamin

\begin{tabular}{cccc}
\hline Jenis Kelamin & Jumlah & Berhasil & \% \\
\hline Laki-laki & 14 & 10 & 71,4 \\
Perempuan & 8 & 4 & 50 \\
\hline
\end{tabular}

Dari tabel di atas diperoleh dari 14 orang pasien laki-laki, 10 orang pasien berhasil dan 4 orang pasien mengalami kegagalan. Dari 8 orang pasien perempuan, 4 orang pasien berhasil dan 4 orang pasien mengalami kegagalan. Prosentase keberhasilan operasi cimino pada pasien lakilaki sebesar 71,4 \% dan prosentase keberhasilan pada pasien perempuan sebesar $50 \%$.

Tabel 2. Distribusi keberhasilan operasi AV-Shunt Cubiti berdasarkan jenis kelamin

\begin{tabular}{cccc}
\hline Jenis Kelamin & Jumlah & Berhasil & \% \\
\hline Laki-laki & 11 & 6 & 54,5 \\
Perempuan & 4 & 3 & 75 \\
\hline
\end{tabular}

Dari tabel di atas diperoleh dari 11 orang pasien laki-laki, 6 orang pasien berhasil dan 5 orang pasien mengalami kegagalan. Dari 4 orang pasien perempuan, 3 orang pasien berhasil dan 
1 orang pasien mengalami kegagalan. Prosentase keberhasilan operasi cimino pada pasien lakilaki sebesar 54,5 \% sedangkan prosentase keberhasilan pada pasien perempuan sebesar 75 \%.

Tabel 3. Distribusi keberhasilan operasi cimino berdasarkan umur

\begin{tabular}{cccc}
\hline Umur & Jumlah & Berhasil & \% \\
\hline $35-44$ & 3 & 2 & 66,7 \\
$45-54$ & 8 & 5 & 62,5 \\
$55-64$ & 5 & 4 & 80 \\
$>65$ & 6 & 3 & 50 \\
\hline
\end{tabular}

Dari tabel di atas diperoleh prosentase keberhasilan operasi cimino pada pasien umur 35 - 44 tahun sebesar 66,7 \%, pasien umur 45 - 54 tahun sebesar 62,5\%, pasien umur 55 - 64 tahun sebesar $80 \%$, dan pasien umur $>65$ tahun sebesar $50 \%$.

Tabel 4. Distribusi keberhasilan operasi AV-Shunt cubiti berdasarkan umur

\begin{tabular}{cccc}
\hline Umur & Jumlah & Berhasil & \% \\
\hline$<35$ & 3 & 1 & 33,3 \\
$35-44$ & 3 & 2 & 66,7 \\
$45-54$ & 3 & 2 & 66,7 \\
$55-64$ & 2 & 1 & 50 \\
$>65$ & 4 & 4 & 100 \\
\hline
\end{tabular}

Dari tabel di atas diperoleh prosentase keberhasilan operasi cimino pada pasien umur $<35$ tahun sebesar 33,3 \%, pasien umur 35 - 44 tahun sebesar 66,7 \%, pasien umur 45 - 54 tahun sebesar 66,7 \%, pasien umur 55 - 64 tahun sebesar $50 \%$, dan pasien umur $>65$ tahun sebesar $100 \%$.

Tabel 5. Distribusi kegagalan penggunaan Cimino berdasarkan waktu

\begin{tabular}{ccc}
\hline Waktu & Jumlah & $\mathbf{\%}$ \\
\hline Pertama kali digunakan & 1 & 12,5 \\
$<1$ bulan pertama & 5 & 62,5 \\
1-3 bulan & 2 & 25 \\
\hline Total & $\mathbf{8}$ & $\mathbf{1 0 0}$
\end{tabular}

Dari tabel di atas diperoleh 1 pasien mengalami kegagalan pada saat pertama kali digunakan (12,5\%), 5 pasien mengalami kegagalan pada pemakaian bulan pertama (62,5\%) dan 2 pasien mengalami kegagalan pada 3 bulan pertama pemakaian (25\%).

Tabel 6. Distribusi kegagalan penggunaan AV-Shunt Cubiti berdasarkan waktu

\begin{tabular}{ccc}
\hline Waktu & Jumlah & \% \\
\hline Pertama kali digunakan & 0 & 0 \\
$<1$ bulan pertama & 3 & 60 \\
1-3 bulan & 2 & 40 \\
\hline Total & $\mathbf{5}$ & $\mathbf{1 0 0}$
\end{tabular}


Dari tabel di atas diperoleh tidak ada pasien mengalami kegagalan pada saat pertama kali digunakan, 3 pasien mengalami kegagalan pada pemakaian bulan pertama (60\%) dan 2 pasien mengalami kegagalan pada 3 bulan pertama pemakaian (40\%).

Tabel 7. Prosentase keberhasilan Operasi Cimino dan AV-Shunt Cubiti

\begin{tabular}{cccc}
\hline Akses Vaskular & Jumlah & Berhasil & $\%$ \\
\hline & & & \\
Cimino & 22 & 14 & 63.6 \\
AV-Shunt Cubiti & 15 & 10 & 66.7 \\
\hline
\end{tabular}

Dari tabel di atas, 22 pasien yang menggunakan Cimino sebagai akses vaskular ditemukan 14 pasien berhasil dan 8 pasien mengalami kegagalan. dan 15 pasien yang menggunakan AV-shunt cubiti sebagai akses vaskular ditemukan 10 pasien berhasil dan 5 pasien mengalami kegagalan. Prosentase keberhasilan penggunaan Cimino sebesar 63,6 \% dan prosentase keberhasilan penggunaan AV-Shunt cubiti sebesar 66,7\%.

\section{PEMBAHASAN}

Terbatasnya data yang diperoleh, peneliti hanya menemukan 22 pasien yang menggunakan operasi Cimino dan 15 pasien menggunakan AV-Shunt Cubiti sebagai akses vaskular untuk hemodialisa. Hal ini tidak menunjukkan fakta bahwa di Manado penyakit gagal ginjal yang terjadi hanya sedikit kasus. Namun kurangnya sampel yang ditemukan peneliti disebabkan oleh kurangnya pasien yang memiliki variabel dan data lengkap. Hal ini perlu diperhatikan karena penggunaan teknik operasi Cimino dan AV-shunt cubiti merupakan akses vaskular yang paling sering digunakan di RSUP Prof Kandou Manado.

Prosentase keberhasilan berdasarkan jenis kelamin berhubungan dengan penyakit penyerta dari pasien. Pada tabel 1 dapat dilihat bahwa pada teknik Cimino prosentase keberhasilan laki-laki lebih tinggi dibandingkan dengan perempuan. Hal yang sebaliknya ditunjukkan pada tabel 2, pada penggunaan teknik AV-Shunt cubiti prosentase keberhasilan perempuan lebih tinggi dibandingkan laki-laki. Penulisan rekam medik yang tidak lengkap dan hilangnya sebagian data mempersulit peneliti dalam mengumpulkan informasi penyakit penyerta dari pasien. Sesuai kepustakaan, pada umumnya pasien dengan ESRD memiliki penyakit penyerta diabetes dan hipertensi. Perempuan lebih banyak menderita diabetes dan hipertensi dibandingkan laki-laki . Hal ini bisa mendukung penelitian bahwa akses vaskular dengan teknik AV-Shunt cubiti memiliki tingkat keberhasilan yang lebih baik dibandingkan dengan teknik cimino untuk pasien-pasien dengan penyakit penyerta diabetes dan hipertensi adalah benar.

Pada tabel 3 dan 4 menunjukkan prosentase keberhasilan berdasarkan umur dari pasien. Prosentase keberhasilan tertinggi pada pasien dengan umur 55-64 tahun pada opersi cimino dan pada umur $>65$ tahun pada operasi AV-Shunt cubiti. Namun, kurangnya sampel penelitian karena data yang tidak lengkap, peneliti tidak dapat memastikan secara pasti hubungan umur dengan tingkat keberhasilan. Faktor yang berkontribusi dengan umur pasien adalah penyakit penyerta seperti diabetes dan hipertensi, histologi dan anatomi vena, komplikasi, dll.

Waktu terjadinya kegagalan yang paling sering adalah pada bulan pertama pemakaian. Dari total 8 kasus yang gagal pada operasi Cimino, 5 diantaranya terjadi pada bulan pertama pemakaian dan dari total 5 kasus yang gagal pada operasi AV-Shunt cubiti, 3 diantaranya terjadi pada bulan pertama pemakaian. Banyaknya kegagalan pada bulan pertama digunakan dikaitkan dengan proses pematangan yang terjadi. Berdasarkan kepustakaan, dibutuhkan waktu 4-6 minggu untuk pematangan agar bisa digunakan. Kemungkinan kegagalan ini terjadi adalah 
belum terjadi pematangan yang baik tapi akses sudah digunakan untuk dilakukan kanulasi. Namun penulisan rekam medik yang tidak lengkap mempersulit peneliti untuk memperoleh data ini.

Dari hasil peneletian yang diperoleh, prosentase keberhasilan Operasi Cimino dan AVShunt Cubiti di RSUP Prof Kandou Manado adalah 63,6 \% untuk Operasi Cimino dan 66,7 \% untuk AV-Shunt cubiti. Sama seperti negara-negara lainnya prosentase keberhasilan dari kedua teknik ini masih harus ditingkatkan. Masih rendahnya tingkat keberhasilan yang ada disebabkan oleh beberapa faktor yang berkontribusi seperti kepatuhan pasien dalam melakukan larangan dan konsultasi pasca bedah. Terdapat beberapa pasien yang sering malas konsultasi pasca bedah, adapun pasien yang tidak melakukan tindakan pasca bedah dengan patuh. Untuk itu dibutuhkan kerjasama yang baik antara pasien serta dokter dalam meningkatkan keberhasilan operasi cimino dan AV-Shunt cubiti.

Peneliti tidak dapat menemukan catatan komplikasi yang muncul pada pasien di rekam medik. Namun berdasarkan observasi yang dilakukan peneliti terhadap pasien secara langsung, terdapat beberapa pasien yang memiliki komplikasi namun tidak ditulis dalam rekam medik. Hal ini sangat perlu diperhatikan dalam pencatatan rekam medik yang dilakukan di RSUP Prof Kandou, mengingat komplikasi yang muncul pada penggunaan akses vaskular cimino dan avshunt cubiti merupakan faktor yang sangat penting. Komplikasi seperti thrombosis, stenosis vena, aneurysm, cardiac failure dan iskemia merupakan penyebab tersering pada kegagalan akses vaskular.

\section{SIMPULAN}

Berdasarkan penelitian yang dilakukan pada 22 pasien cimino dan 15 pasien AV-Shunt Cubiti di RSUP Prof Kandou ditemukan prosentase keberhasilan penggunaan Cimino sebesar 63,6 \% dan prosentase keberhasilan penggunaan AV-Shunt cubiti sebesar 66,7\%.

\section{DAFTAR PUSTAKA}

1. Centers for Disease Control and Prevention. National Chronic Kidney Disease Fact Sheet: Chronic Kidney Disease Initiative Protecting Kidney Health. Atlanta, GA: U.S. Department of Health and Human Services, CDC; 2012.

2. National Kidney Foundation. K/DOQI clinical practice guidelines in vascular access: 2006 update. Am J Kidney Dis 2006; 48 (Suppl 1): 241-395.

3. Daugirdas JT. Handbook of Dialysis $3^{\text {rd }}$ Edition. New York : Lippincott Williams \& Wilkins Publishers, 2000.

4. Hammes M. Hemodialysis Access: The Fistula. University of Chicago, United States. 2011

5. Gunatillake ND, Jarvis EM, Johnson DW. Hemodialysis Access Infections, Epidemiology, Pathogenesis and Prevention. Department of Nephrology, Pricess Alexandra Hospital, Brisbane Australia. 2011

6. Fistula First. A Practitioner's Resource Guide to Hemodialysis Arteriovenous Fistulas. End Stage Renal Disease Network of Texas, Inc. (\#14). 2003

7. Pantelias K, Grapsa E. Vascular Access for Hemodialysis. University of Athens.Greece.2011

8. Sukerto T. Akses Hemodialisa. 2009. Diakses 1 Oktober 2013. Available from : http://bedahumum.com/bu/index.php

9. Beathard GA. Physical Examination of the Dialysis Vascular Access. 2007

10. Fistula First. A Practitioner's Resource Guide to Physical Examination of Dialysis Vascular Access. End Stage Renal Disease Network of Texas, Inc. (\#14). 2003. 
11. National Kidney Foundation. K/DOQI clinical practice guidelines in Hemodialysis Adequancy: 2006 update. Am J Kidney Dis 2006; 48 (Suppl 1): 10-60.

12. Shohaib SA, Waness A, Sayyari AA. Hemodialysis Angioaccess Choice and Survival in a Tertiary Care Saudi Arabian Center from 1993 to 2004. International Journal of Nephrology \& Urology, 2011;3(1):69-73 